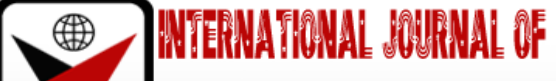

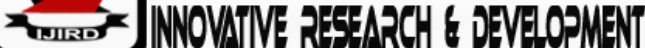

ISSN $2278-0211$ (Online)

\section{Anti-Corruption Agencies and Eradication of Corruption in Nigeria}

\author{
Dr. Azeez, Ademola I \\ Associate Professor, Department of Political Science, College of Social and Management Sciences, \\ Afe Babalola University, Ado-Ekiti, Ekiti State, Nigeria \\ Ajibowu-Yekini, Maito S \\ Associate Professor, Department of Political Science, College of Social and Management Sciences, \\ Afe Babalola University, Ado-Ekiti, Ekiti State, Nigeria
}

\begin{abstract}
:
Corruption has been identified in the literature as one of the major factors hindering the development of nations like ours. Hence, the study investigated activities of anti-corruption agencies such as Economic and Financial Crimes Commission (EFCC), and Independent Corrupt Practices and other related offences Commission, with Code of Conduct Bureau and Money Laundering Act in eradicating corruption in Nigeria. With the use of survey research design, primary data were sourced through the administration of 150 questionnaires to the staffs of EFCC and ICPC across the Western States in Nigeria. These were analyzed using tables, frequencies and chi-square methods. It was found that, the activities of anti-corruption agencies have significantly helped in eradicating corruption in Nigeria, much more with the existence of the Code of Conduct Bureau and Money Laundering Act. However, much is expected from ICPC because it was found to be sluggish in their activities in eradicating corruption in Nigeria. It was concluded that, though fighting corruption, both at the low and high places in Nigeria, seems to be highly tasking, the anti-corruption agencies roles in eradicating corruption cannot be overemphasized. It is therefore recommended that, adequate funds and facilities should be provided for the agencies so as to enable they perform their roles efficiently. More importantly, qualified and non-political personnel should be recruited into the commission, and a special court should be set up to fast-track the trial and prosecution of any individual found or caught with any form of corruption in Nigeria.
\end{abstract}

Keywords: Corruption, anti-corruption agencies, money laundering

\section{Introduction}

Corruption has been acknowledged in the literature as a phenomenon that hinders development of a nation and as such, it is a practice that is common among the political settings. This does not mean, corruption cannot be found among individuals who do not hold public office, but the fact that, the public officers are entrusted with the public funds that are meant for the economic development and to be given proper account of such funds, makes it more pronounced among the politically exposed people. Frantically, corruption, either politically, intellectually, economically, morally or electorally etc. are not desirable, as it reduces resources meant for development, undermines growth and send wrong signals to the world, most especially to the foreign investors(Okechukwu, Igwe \& Ezenwafor, 2017)

In Nigeria, since the return of democratic government, there are lots of corruption cases pending which ought to have attended to, but unfortunately, not much has been done. There are cases that have gone deep in sleep, there are some not tried but granted bail, some are discharged and acquitted while there are some that are pardoned(Usman, 2014). Obviously, it is worrisome that with the levity hands in which the past administrations in this country have attended to these corrupt cases, its incidence has gone so deep into the garment of Nigerian economy to the extent that, when people in public offices steal or misappropriate public funds with evidence, they eventually escape justice. This is supported by the statement of Owosanoye (2014) which says, many of high corrupt profiles are hanging due to the unnecessary prolonged trials and frequently adjournments for flimsy excuses. He submitted that, once a case gets to hibernation, accused is empowered to clean up the crime trail, negotiate with or frustrate prosecution, peddle political influence to pressure prosecution and influence and frustrate the court.

Nigerians have overwhelmingly suffered from the negative effect of corruption and continuous tolerance for corruption in the land has caused very high rate of poverty, insurgency, conflict, unemployment, underdevelopment, low standard of living in Nigeria (Ajodo-Adebanjoko \&Okorie, 2014). Not only that, corruption has found its way into all public offices and has led in crippling the due process in government establishment, making it difficult to be eradicated. As said 
inconsistence and up till date, there have not been serious and concerted effort or strategy towards addressing the problem because, challenges with fighting corruption in developing countries especially in Africa is that everybody in government is deeply involved. That is, from the Head of State, Ministers, State and Local council officers down to the lowest ranks of public officers with the purpose of gainingillicit advantage in whatever form to the overall detriment of the state and the economic system as a whole.

As a consequence of the above, there were establishment of an independent commission against corruption such as, Criminal Code, Penal Code, Criminal Justice (Miscellaneous Provision) Decree1966, and the Corrupt Practices Decree No.38 of 1975, the Code of Conduct (Bureau and Tribunal) under the constitution, and the Recovery of Public Property Decree of 1984, with the hope of bringing about change in the system to reduce the rate of corruption in the economy. Also, in 1991 the National Committee on Corruption and Economic Crimes recommended the establishment of the following anti-corruption mechanism which include, Ethical Re-orientation Campaign of Shagari's second republic, War Against Indiscipline (WAI) of the Buhari/Idiagbon regime, Babangida's Committee on Corruption and other Economic Crimes, the numerous probe panels of the Abacha years and the Jaji Declaration of the Muritala/Obasanjo administration (Fagbadebo 2007). It is saddened that, none could achieve the purpose.

In 2000, as a result of the failure of the above-mentioned mechanisms, there was another establishment of independent corrupt practices and other related offences commission (ICPC) and in 2003; another independent anticorrupt agency was established called economic and financial crime commission (EFCC) (Ibrahim, Umar \& Ajoke, 2013). Both have the mandate to enforce and administer the provisions of the Economic and Financial Crimes Commission Act by investigating all financial crimes, including advanced free fraud, money laundering, counterfeiting, illegal cash transfer, credit card fraud contract scams, etc. and investigating and prosecuting corrupt individuals. Since their establishment, there have been war and pressure to kill the institutions from carrying out their responsibilities. However,in recent time, the institutions have been after political officers, much money has been recovered, many arraigned, some chief executives and governors are jailed and there is fear in the land. (Nwaodu\& Okereke, 2014)

Although, studies such as Ocheci and Nwankwo, (2012) are of the opinion that, much has not been done by these institutions, however, continuous assessments of the institutions are paramount so as to further weigh their efforts and roles in eradicating corruption in Nigeria. More importantly, many studies approach has been qualitative o contextual in nature; this study therefore employed a survey method to elicit responses from the commission staff so as to make a concrete conclusion and recommendations for policy initiatives. Hence, the study examined the activities of anticorruption agencies in eradicating corruption in Nigeria. the following hypotheses are also stated to guide the study

\subsection{Statement of Hypotheses}

- $\mathrm{Ho}_{1}$ : There is no significant relationship between Economic and Financial Crimes Commission and corruption eradication in Nigeria

- $\mathrm{Ho}_{2}$ : There is no significant relationship between Independent Corrupt Practices Commission and corruption eradication in Nigeria

- $\mathrm{Ho}_{3}$ : There is no significant relationship between Code of Conduct Bureau and corruption eradication in Nigeria

- $\mathrm{Ho}_{4}$ : There is no significant relationship between Money Laundering Prohibitions Act and corruption eradication in Nigeria

\section{Literature Review}

\subsection{Conceptualization of Corruption}

Gboyega (1996) arrive at a definition of corruption as being any decision, act or conduct that was perverse to democratic norms and values. It also covers any decision, act or conduct that subverted the integrity of people in authority or institutions charged with promoting, defending or sustaining the democratization process, thereby undermining its effectiveness in performing its assigned roles. The importance of this definition is that, corruption or corrupt behaviour involves the violation of established rules for personal gain and profit. It is to secure wealth or power through illegal means, that is, private gain at public expense and it is a misuse of public power for private benefit

Bardhan(1997) see corruption as the practice where a government official requested for a bribe from a foreign business or investors in return for the right to operate in a country, industry or a specific location. This explains the dilemma faced by the investors from outside of the country before they can be allowed from operating in a country outside their home countries. Majorly, this type of corrupt act gives the investors power and right to discriminately manipulate prices or products so as to make more gains from the populace

Ogundele and Opeifa (2004) describe corruption as consisting of several elements which include, deceit, trickery, cheating, intentional deception, dishonesty and the conscious premeditated action of a person or group of persons to alter the facts of a matter or transaction for the purpose of selfish personal gains. This means that corruption involves an intentional perversion of the truth or a deliberate manipulation of facts and situation at one's disposal to gain illegitimate material and nonmaterial advantages.

From the above, it can be inferred that, corruption has no uniform definition. This is because what is regarded as corruption depends on the actors, the profiteers, initiators, how and where it takes place. It also depends on the existing laws and regulations guiding certain actions. Some countries define corruption in the broadest form while others legislated on the narrow definition of the term. Irrespective of how a nation perceives the definition of corruption in its economy, corruption retards economic growth of a nation; hence a stumbling block to its progress. (Egunjobi, 2013) 
However, there are many classifications of corruption as explained by Ikpeze(2013) and these are petty corruption and grand corruption. The former refers to minor corrupt practices such as those involving small amounts of money, dispensation of minor favours by persons seeking preferential treatment or the employment of friends or relatives into minor positions. On the other hand, the later refers to large scale corrupt practices which exist or occur at the highest levels of government and which erode public confidence in good governance, rule of law and negates economic progress or stability. In addition, it can also be classified as political corruption, bureaucratic corruption and economic corruption. The political corruption is a form of corrupt practices which involves vote-rigging, manipulation of the voter's register, the falsification of election results and other corrupt acts aimed at capturing the apparatus of government or the control of political power. In the same vein, bureaucratic corruption refers to efforts by civil servants to enrich themselves through illegal means while the economic corruption is majorly found in the financial institution such as banks, insurance companies and entire economic as a whole (Ikpeze, 2013;Ibrahim 2014)

In respective of the forms or classifications of corruption, Ocheni and Nwankwo(2012) elicit causes of corruption practices to include culture and weird value system of the society and poor reward system. From Oguonu and Chuwuebuka(2014) poverty and hunger was elicited as one of the causes of corruption. In an elaborate dimension,Shuiab(2015) listed the following as the causes or factors responsible for corruption in Nigeria; weak institution of government, lukewarm attitude of the law enforcement agents, cultural and institutional factors such as nepotism and strength of the family values, poor reward system and low remuneration for public servants, bureaucratic bottlenecks, absence of transparency in financial institutions

Hence, corruption manifests itself inform of payments, money laundering, drug trafficking, falsification of documents and records, window dressing, false declaration, aiding and abetting of any kind (James, 2012). In addition, corruption can also manifest itself through declarations, abuse of office, unconventional and fraudulent trade practices, under- and over- invoicing, collection of illegal tolls, unauthorized use of resources for private gain, impairment of integrity, virtue or moral principles, misuse of official power for selfish motive, perversion of public rules, refusal to declare one's assets on the assumption and expiration of public office, using one's official status to foil the administration of justice, the thwarting of the electoral process to make free and fair election impossible and faulty recruitment of mediocre or totally unsuitable candidates in preference to candidates of high merit in the Nigerian Public Service (Afolabi, 2007).

In eradicating all forms of corrupt practices in Nigeria, several strategies, inform of establishment of commissions to fight corruption have been instituted in the past with little no results, as there was evidence of continuous increase of corruption practices ravaging the land. Immediately there was return of democratic government in 1999, there was an effort in establishing two forms of anti-corruption agencies which are Independent corrupt practices and other related crimes commission, this was established in 2000 and in 2003, another agency calledEconomic and financial crimes commission to further strengthened their efforts in ensuring that corruption is reduced to the barest minimum in the society.

The main mandate of Independent corrupt practices and other related crimes commission is to investigate reports of corruption, review government systems prone to corruption and educate the public while, ICPC has been acclaimed as the cornerstone in the fight against corruption in Nigeria (Nigeria corrupt Index 2007). However, the commission has been sluggish in its fight due to some logistics as adduced by its chairman. It is worth noting that the commission acts mainly upon petition or report of allegation of corruption against a public officer. Despite this, immediately after its inauguration, there are several success reports. According to Eweremandu(2010), as at 2007, the number of cases in the court rose to 161 involving 309 persons while only 20 were persecuted and other cases remain stagnant

On the other hands, economic financial crimes commission was established as results of constrained power on the part of ICPC as the act that established it was limited to public officers. With the establishment of EFCC, there was wider coverage which do not limit its power to public officers alone but include mandate in conducting investigations of crimes of financial and economic nature, corruption, money laundering, advance fee fraud or 419, bank fraud, etc., whether in the public or private sector, and arresting and prosecuting the perpetrators of such crimes. There were lots of success stories on the part of EFCC and as a result, received public support but among the government officials that created it, the commission is being seen as a discomfort because it has made the political officers its target, as they are seen as the great perpetrator of corruption in Nigeria (Eweremandu, 2010)

\subsection{Empirical Review}

Okechukwu and Chukwuma(2011) examined the role of Efcc in combating political corruption in Nigeria using qualitative approach method. The study showed that, political corruption undermines the democratic process and leads to a compromising of democratic ideals, the growth of political apathy among electors, mistrust of the electoral process and authorities, and the consolation of authoritarian tendencies in the polity. It was suggested that INEC, EFCC and other anticorruption and security agencies should be empowered and grant absolute autonomy to handle cases relating to political corruption. Anticorruption laws, legislations and regulations should be written in simpler language and made accessible to the populace.

Ocheci and Nwankwo (2012) evaluated the effectiveness of anti-corruption agencies in enhancing good governance in Nigeria using a qualitative approach method. It was revealed that, much has not been achieved by the agencies and in order to redeem their image, there is need for both EFCC and ICPC to develop the political will to prosecute corrupt people no matter how highly placed. In addition, they suggest that the modus operandi of EFCC should change and there must be need for proper funding of these agencies without which may frustrate their efforts Ikpeze(2013)critically studied the fusion of anti-corruption agencies in Nigeria using a qualitative approach method. The study revealed that the 
country has demonstrated concern for curbing corruption through diverse legislation. These laws also established many institutions and agencies for the implementation and enforcement of anti-corruption measures. But there are varied conflicts surrounding these laws, agencies and the institutions for the enforcement of anti -corruption laws. He suggested that these conflicts must be resolved if the anti-corruption crusade is to continue to be beneficial, the agencies should be reduced to make supervision and control easier. If there is no control, the excesses or problems of the agencies like human rights abuses, disobedience to court orders, manipulations through function-switching by the executive, lack of coordination about anti-corruption activities among the agencies would rather exacerbate than abate.

Nwaodu, Adam and Okereke (2014) explored the anti-corruption war in Nigeria using a narrative-textual case method. It was revealed that, the agency has made some successes but is being hindered by political, administrative and judicial bureaucracy from efficient performance. It was suggested that transparency should be enshrined into all aspect Nigerian political and administrative life and extant anti-graft laws be reviewed, harmonized and strengthened to enhance the effectiveness of eradicating corruption and breach of corporate governance ethics by those holding political and nonpolitical positions in Nigeria.

Shuaib(2015) investigated causes, effect and solution of corruption in Nigeria. using a qualitative method approach, it was found that, there are many factors adduced to have been responsible for continuous increase in the level of corruption in Nigeria amongst which is the institutional factors and the effects are manifested in the decay infrastructure and decline in people's standard of living. it was suggested thatan effective action against corruption has to evolve effective sanction and greater political transparency as a means of ensuring that the resources of the country are deployed to bring about sustainable development in the country.

Ethelbert (2016) assessed the challenges of managing corruption in Nigeria by economic financial crimes commission using a qualitative approach methods, it was revealed that the Commission is confronted with myriad of challenges which include meddling in its activities by the power elites; unwholesome judicial process; weak anti-graft laws; job insecurity for its Chairperson and to enhance the smooth operation of the commission, special courts need to be granted the commission; repealing of laws which hinder their operation, also the agency must be free from any form of executive and legislative influences among other

Okechukwu et al(2017) also evaluated challenges and solution to the African anti-corruption agencies with the use of qualitative approach method. It was found that right sizing the state and political liberalization are desirable goals in many African states; they are necessary rather than sufficient conditions for the reduction of corruption. They are of the opinion that, extensive public and private sector corruption can coexist with democratic politics and economic liberalization can also create avenues for corruption, through the sale of parastatal in dubious circumstances. For anticorruption strategies to be effective in the continent, more attention needs to be devoted to questions of sequencing, the details of reform and its sustainability in very poor polities, political will and commitment

Shiyanbade, Bello, Diekola and Wahab(2017) assessed the efficiency and impact of national anti-corruption institutions in the control of corruption in Nigeria using content analysis. It was discovered that, corrupt practices in Nigeria system is tight to institutional weaknesses and system failure as a result of government interfere in the day-to-day activities of these anti-corruption institutions. In addition, it was also discovered that, even though efforts were geared towards the prosecution of corrupt individuals and agencies, enduring policies for the prevention of these negative activities still remained. It was suggested that, autonomy of these anti-corruption crusade calls for total overhaul of the institutions and a set of harmonized policies remain critical for a successful battle against corruption in Nigeria

\section{Methodology}

The study employed survey research design which is qualitative in nature. Base on this, primary data were sourced from the EFCC, ICPC staff in Nigeria. The population of the study consist all the 36 states in Nigeria where the commission have office. 150 participants were purposively selected to elicit responses pertaining to their activities through a structured questionnaire administered. The questionnaire was structured using 6Likert scaling to enable researcher have the perception of the participants on each of the questions. In analyzing the responses, the study employs tables, percentages and hypotheses were tested using chi-square method.

\section{Results and Findings}

Table 2 in the appendix revealed the characteristics of the participants employed in the study. Sex status reflects that male and female represented $60 \%$ and $40 \%$ and their age ranges between $21-30(4 \%), 31-40(30 \%), 41-50(50 \%)$ and 50 above (13\%). It represents $57 \%$ Christians and $43 \%$ Muslims while their marital status indicated that $87 \%$ of the participants are married and $13 \%$ were single. Their education background also revealed that, $7 \%$ of the participants have Msc/MBA, 57\% have Bsc, HND represents 31\% and 15\% represented the participants with National Diploma.

Table 3 in the Appendix displayed the perception of the participants on the effectiveness of economic financial crimes commission in eradicating corruption in Nigeria. The study revealed that majority of the participants are of the opinion that Efcc has been effective in their activities by alerting banks on repercussion of aiding money laundering in their banking operations. It also revealed that majority of the participants are of the opinion that Efcc are effective in their oversight function. Majority of the respondents are also of the opinion that, it is not in all cases that unemployed youths are used to perpetrate political crimes. They were of the view that despite the fact that Efcc has been trying to eradicate corruption through their activities, this does not serve as a deterrent to others as corruption continue to ravaged the land and lastly, it was revealed that in the recent, Efcc has been efficient and effective in their activities in eradicating corruption in Nigeria 
Table 4 in the Appendix showed the perception of the participants on the effectiveness of ICPC in eradicating corruption in Nigeria. It revealed that, participants are of the opinion that the activities and efforts of the ICPC are hindered by the activities of the court; although majority of the participants are of the views that the agency has been effective in directing, examining the practice, system and procedures of the public bodies and complaints, and also that it has been available to investigate complaints from the public on allegations of corrupt practices. However, it has not been effective and efficient in ensuring that the offenders are prosecuted in appropriate cases that has to do with corruption Table 5 in the appendix revealed the perception of the participants regarding the activities of the code of conduct bureau in eradicating corruption in Nigeria. The survey revealed that the participants are of the opinion that, code of conduct from their activities has been able to forestall conflict of interest in the public offices. Not only that, it also revealed that the commission has been able to restrict public officers in maintaining bank account of any sort outside the country. However, the participants disputed the fact that despite the activities of the commission, that has not stopped the public officers from collecting gifts and benefits of any kinds. In regards to asset declaration, the participants of the opinion that the commission has effectively enable the public officers in declaring their assets to the commission. Notwithstanding, the commission is also effective in ensuring compliance of public officers in assets declaration, moral standard and probity.

Table 6 in the appendix revealed the perception of the participants in respect of effectiveness of the money laundering act in eradicating corruption in Nigeria. Its findings showed that majority of the participants are of the views that the act has not helped in reducing laundering of money in the country and has not actually enhance reduction in the level of financial terrorism in Nigeria. More importantly, it was revealed that the participants are of views that it has prevented the existence of and dominance of anonymous account in banks but it has not been effective and efficiently prosecute culprits. However, it has made the financial institutions to be cautious in their dealing with money launderers

\begin{tabular}{|c|c|c|c|c|}
\hline $\mathbf{S} / \mathbf{N}$ & Hypotheses & Df and level of Sign & Chi-Square and P-value & Decision \\
\hline 1 & $\mathrm{H}_{\mathrm{o} 1}$ & $5 \quad(5 \%)$ & $120.97 \quad(0.001)$ & Accept Alternate \\
\hline 2 & $\mathrm{H}_{02}$ & $16 \quad(5 \%)$ & $22.7 \quad(0.11)$ & Accept Null \\
\hline 3 & $\mathrm{H}_{03}$ & $5 \quad(5 \%)$ & $(0.001)$ & Accept Alternate \\
\hline 4 & $\mathrm{H}_{04}$ & $5 \quad(5 \%)$ & $139.15 \quad(0.000)$ & Accept Alternate \\
\hline
\end{tabular}

Table 1: Results of the Hypotheses

Source: Authors Computation From SPSS

From the table 1 above, it is revealed that the test for the three hypotheses were accepted indicating that EFCC, CCB and Money laundering act have significant impact on corruption eradication in Nigeria. While the second hypothesis indicated that ICPC has limited impact on corruption eradication in Nigeria. However, for the first hypothesis, the $\mathrm{p}$-value $=$ (0.01). Since p-value $=0.001<0.05$, the null hypothesis is rejected and alternate accepted which indicates that EFCC has impact in eradicating corruption in Nigeria. The second hypothesis also revealed the P-value is $(0.11)$. since the p-value 0.11 is $>0.05$, the study therefore cannot reject the null hypothesis indicating that ICPC has no significant impact in eradicating corruption in Nigeria. Likewise, the third hypothesis p-value is $0.001<0.05$. since p-value is lesser than $5 \%$ level of significant, it is accepted that CCB has significant impact on corruption eradication in Nigeria and lastly, result from money laundering act shows that the p-value of $0.01<0.05$. Since $\mathrm{p}$-value is lesser that $5 \%$, it is also accepted that money laundering act has significant impact in eradicating corruption in Nigeria. This position, is in line with the study of Nwaodu et al 2014 but are of negative stance with the study of Ocheci and Nwankwo, (2012)

\section{Conclusion and Recommendations}

Having empirically examined the activities of anti-corruption agencies in eradicating corruption in Nigeria, the study therefore concluded that, anti-corruption agencies such as EFCC and complement activities of CCB and Money laundering act has been able to reduce the level of corruption while the ICPC was seen to be sluggish in its activities towards corruption eradication in Nigeria. However, much is still expected from these anti-corruption agencies because the incidence of corruption has really gone deep into the Nigeria economy system and it requires continuous effort from them to ensure that the purpose of their establishment is achieved. Hence, the study recommends that, adequate funds and facilities should be provided for the agencies so as to enable they perform their roles efficiently. Not only that, the agencies should be given autonomy to arrest, charge, prosecute and jail perpetrators of corruption in Nigeria no matter how highly place they may be. This will serve as deterrent for others and consequently, helps in reducing corruption to minimum. More importantly, qualified and non-political personnel should be recruited into the institutions and a special court should be set up to fast-track the trial and prosecution of any individual found or caught with any form of corruption in Nigeria. ICPC should be more empowered so as to function more in their activities in eradicating corruption in Nigeria and lastly, the agencies should carry out an intensive sensitization of the whole public about the evil in perpetrating corruption and the likely punishment for such offenders if found wanting. With this it is believed that, corruption may be reduced and eradicated from the system

\section{References}

i. Afolabi, G. K. (2007). Contextual perceptions of corruption in contemporary Nigeria. An International Multi-Disciplinary Journal, Ethiopia, 4(1), 309-321

ii. Ajodo-Adebanjoko, A., \& Okorie, N. (2014). Corruption and the challenges of insecurity in Nigeria: Political economy implications, Global Journal of Human-Social Science, 14(5), 1-16

iii. Bardhan, P. (1997). Corruption and development: A review of issues. Journal of Economics Literature, 35(3), 1320-1346 
iv. Egunjobi, T.A. (2013). An econometric analysis of the impact of Corruptionon economic growth in Nigeria. Journal of Business Management and Economics, 4(3), 54-65

v. Enweremadu, D.U.(2010). Anti- corruption policies in Nigeria under Obasanjo and Yaradua:

What to do after 2011. Discussion Paper No 1, 1-30

vi. Ethelbert, O.L.(2016). Economic and financial crimes commission (EFCC) and the challenges of managing corruption in Nigeria: A Critical Analysis. International Journal of Scientific and Research Publications, 6(4), 339-349

vii. Fagbadebo, 0.(2007). Corruption, governance and political instability in Nigeria. African Journal of Political Science and International Relations, 1(2), 28-37

viii. Gboyega, A., (1996). Corruption and democratization in Nigeria (1983- 1993): An Overview Friedrich Elbert Foundation, Agbo AreoPublishers, Ibadan

ix. Ibrahem, N., Umar, G., Ajoke, A.F. (2013). Corruption and Economic Development: Evidence from Nigeria. Journal of Business Management Review, 3(2),

x. Ikpeze, N.(2013). Fusion of anti-corruption agencies in Nigeria. A Critical Appraisal. Afe Babalola University: Journal of Sustainable Development Law and Policy, 1(1), 148-167

xi. James, U.(2012). The Impact of Corruption on the socioeconomic development of Nigeria. Crown Research in Education, 2(3), 143-152

xii. Nwaodu, N., Adam, D., \& Okereke, 0. (2014). A review of Anti- corruption wars in Nigeria. Africa's Public Service Delivery \& Performance Review, 153-174

xiii. Ocheni, S., \& Nwankwo, B.C. (2012). The effectiveness of anti-corruption agencies in enhancing good governance and sustainable developmental growth in Africa: The Nigeria Paradox under Obasanjo Administration, 20032007.Canadian Social Science, 8(3), 16- 21

xiv. Ogundele, O.J.K., \& Opeifa, A.Z. (2004). Importance of ethical education in economic and social reconstruction.Nigerian Journal of Curriculum and Instruction, 2(2), 164 - 169.

xv. Oguonu, C.N., \& Ezeibe, C.C. (2014). Political corruption and economic growth in Nigeria. Mediterranean journal of social sciences, 5(27), 69-76

xvi. Okechukwu, E.I., \& Chukwuma, O.I. (2011). The role of EFCC in combating political corruption in Nigeria. Arabian Journal of Business and Management Review, 1(3), 45-67

xvii. Okechukwu, I.E.,Igwe, I.S., \& Ezenwafor, E.C.(2017). African anti-corruption agencies: Challenges and Prospect. Management Studies and Economic Systems, 3(4), 225-243

xviii. Owosanoye, B (2014). Stop Impunity Nigeria. http://stopimpunitynigeria.org

xix. Shiyanbade, B.W., Bello, A.M., Diekola,O.J., \& Wahab, Y.B. (2017). Assessing the efficiency Science, 22(7), 56-64

xx. Shuaib, O.M.(2015). Corruption in Nigeria: Causes, Effects and Probable Solutions. Journal of Political Science and Leadership Research, 1(8), 22-36

xxi. Usman, M. (2014). Corruption in Nigeria: A challenge to sustainable development in the fourth republic. European Scientific Journal, 9(4), 118-137

\section{Appendix}

\section{Respondents Bio-Data}

\begin{tabular}{|c|c|c|c|}
\hline Variables & Categories & Frequency & (\%) \\
\hline & Male & 60 & 40 \\
\hline Sex & Female & 90 & 100 \\
\hline & Total & 150 & 4 \\
\hline & $21-30$ years & 5 & 30 \\
\hline Age & $31-40$ years & 45 & 53 \\
\hline & $41-50$ & 80 & 13 \\
\hline & above 50 & 20 & 57 \\
\hline & Total & 150 & 43 \\
\hline & Christianity & 86 & 100 \\
\hline & Islam & 64 & 13 \\
\hline Religion & Total & 150 & 87 \\
\hline & Single & 20 & 100 \\
\hline & Married & 130 & 7 \\
\hline Marital Status & Total & 150 & 57 \\
\hline & M.sc./MBA. & 10 & 21 \\
\hline & Bs.c & 86 & 15 \\
\hline & HND & 31 & 100 \\
\hline & ND & 23 & 150 \\
\hline
\end{tabular}

Table 2: Frequency Distribution of Demography Variable $(N=150)$

Source: Field Survey, 2018 


\begin{tabular}{|c|c|c|c|c|c|c|c|}
\hline S/N & $\begin{array}{c}\text { Strongly Agree (SA), Agree (A), Partially Agree(PA), } \\
\text { Partially Disagree (PD) Disagree (D) Strongly } \\
\text { Disagree (SD }\end{array}$ & SA(\%) & A(\%) & PA(\%) & PD(\%) & D(\%) & SA(\%) \\
\hline & $\begin{array}{c}\text { EFCC has been alerting banks of the grave } \\
\text { repercussions of aiding money laundering? }\end{array}$ & 17.78 & 34.62 & 32.84 & 14.19 & 2.02 & 16.67 \\
\hline & $\begin{array}{l}\text { EFCC has been effective in its oversight function over } \\
\text { the publication and distribution of revenue from the } \\
\text { federation account? }\end{array}$ & & & & & & \\
\hline & $\begin{array}{c}\text { To what extent do you agree that unemployed youths } \\
\text { are used to perpetrate political crimes? }\end{array}$ & 17.78 & 23.08 & 7.46 & 29.03 & 30.30 & 35.09 \\
\hline & $\begin{array}{c}\text { cases prosecuted by EFCC have been able serve as a } \\
\text { deferent to other financial criminals in both public and } \\
\text { private institutions? }\end{array}$ & 15.38 & 14.93 & 19.35 & 10.10 & 17.54 \\
\hline & $\begin{array}{l}\text { EFCC has been so efficient and effective in the recent } \\
\text { anti-corruption war? }\end{array}$ & 24.44 & 11.54 & 29.85 & 11.61 & 22.22 & 17.54 \\
\hline
\end{tabular}

Table 3

\begin{tabular}{|c|c|c|c|c|c|c|c|}
\hline S/N & $\begin{array}{c}\text { Strongly Agree (SA), Agree (A), Partially } \\
\text { Agree(PA), Partially Disagree (PD) Disagee } \\
\text { (D) Strongly Disagree (SD }\end{array}$ & SA(\%) & $\mathrm{A}(\%)$ & PA(\%) & PD(\%) & $\mathrm{D}(\%)$ & SA(\%) \\
\hline 1 & $\begin{array}{c}\text { Has court system in Nigeria allows for effective } \\
\text { operations of ICPC? }\end{array}$ & 16.67 & 25.68 & 34.67 & 24.88 & 11.49 & 13.16 \\
\hline 2 & $\begin{array}{l}\text { ICPC has been effective and efficient in examining } \\
\text { the practice, system and procedures of public } \\
\text { bodies whether they aid corruption or not? }\end{array}$ & 20.00 & 31.08 & 6.67 & 22.39 & 8.05 & 43.42 \\
\hline 3 & $\begin{array}{l}\text { ICPC has been able to direct, supervise and review } \\
\text { the practical, system and procedures of public } \\
\text { bodies, which aid corruption? }\end{array}$ & 23.33 & 18.92 & 21.33 & 29.85 & 10.92 & 7.89 \\
\hline 4 & $\begin{array}{l}\text { ICPC has been effective in recurring and } \\
\text { investigating complaints from the public on } \\
\text { allegations of corrupt practices? }\end{array}$ & 26.67 & 16.22 & 17.33 & 11.44 & 31.61 & 9.21 \\
\hline 5 & $\begin{array}{l}\text { ICPC has been effective in recurring and } \\
\text { investigating complaints from the public on } \\
\text { allegations of corrupt practices? }\end{array}$ & 13.33 & 8.11 & 20.00 & 11.44 & 37.93 & 26.32 \\
\hline
\end{tabular}

Table 4

\begin{tabular}{|c|c|c|c|c|c|c|c|}
\hline$S / N$ & $\begin{array}{l}\text { Strongly Agree (SA), Agree (A), Partially } \\
\text { Agree(PA), Partially Disagree (PD) Disagee } \\
\text { (D) Strongly Disagree (SD }\end{array}$ & SA(\%) & $\mathrm{A}(\%)$ & PA(\%) & PD(\%) & $\mathrm{D}(\%)$ & SA(\%) \\
\hline 1 & $\begin{array}{l}\text { t code of conduct bureau and tribunal has been } \\
\text { able to forestall conflict of interest in public } \\
\text { officers? }\end{array}$ & 17.24 & 28.93 & 16.13 & 19.87 & 21.36 & 16.98 \\
\hline 2 & $\begin{array}{c}\text { code of conduct of bureau and tribunal has been } \\
\text { able to restrict public officers in maintaining or } \\
\text { operating a bank account in any country outside } \\
\text { Nigeria? }\end{array}$ & 20.69 & 21.49 & 17.74 & 19.87 & 12.62 & 27.36 \\
\hline 3 & $\begin{array}{l}\text { code of conduct of bureau and tribunal has been } \\
\text { able to restrict public officers against } \\
\text { acceptance of gifts and benefits in kind? }\end{array}$ & 15.17 & 13.22 & 9.68 & 37.75 & 16.50 & 24.53 \\
\hline & $\begin{array}{l}\text { public officers have been genuinely declaring } \\
\text { their assets due to the operations of code the } \\
\text { code of conduct bureau and tribunal? }\end{array}$ & & & & & & \\
\hline 4 & & 30.34 & 23.14 & 20.16 & 10.60 & 21.36 & 14.15 \\
\hline 5 & $\begin{array}{l}\text { code of conduct of bureau has been effective and } \\
\text { efficient in ensuring compliance of public } \\
\text { officers in assets declaration, moral standards } \\
\text { and probity? }\end{array}$ & 16.55 & 13.22 & 36.29 & 11.92 & 28.16 & 16.98 \\
\hline
\end{tabular}

Table 5 


\begin{tabular}{|c|c|c|c|c|c|c|c|}
\hline S/N & $\begin{array}{c}\text { Strongly Agree (SA), Agree (A), Partially } \\
\text { Agree(PA), Partially Disagree (PD) } \\
\text { Disagee (D) Strongly Disagree (SD }\end{array}$ & SA(\%) & $\mathrm{A}(\%)$ & PA(\%) & PD(\%) & $\mathrm{D}(\%)$ & SA(\%) \\
\hline 1 & $\begin{array}{c}\text { existence Money Laundering Act in Nigeria } \\
\text { has reduced Money Laundering } \\
\text { drastically? }\end{array}$ & 12.65 & 16.83 & 16.46 & 42.11 & 20.95 & 18.37 \\
\hline 2 & $\begin{array}{l}\text { Money Laundering Act in Nigeria has been } \\
\text { able to prevent financial terrorism, the } \\
\text { Laundering of the proceeds of crime or } \\
\text { insurgencies? }\end{array}$ & 21.34 & 22.77 & 20.25 & 10.53 & 12.38 & 32.65 \\
\hline & $\begin{array}{l}\text { Money Laundering Act has been able to } \\
\text { prevent the existence and dominance of } \\
\text { anonymous accounts in banks? }\end{array}$ & & & & & & \\
\hline 3 & & 22.53 & 21.78 & 20.25 & 14.91 & 27.62 & 9.18 \\
\hline 4 & $\begin{array}{l}\text { Money Laundering (prohibitions) Act has } \\
\text { been used effectively to prosecute culprits } \\
\text { and offenders in Nigeria? }\end{array}$ & 18.97 & 14.29 & 24.05 & 21.93 & 25.74 & 17.35 \\
\hline 5 & $\begin{array}{l}\text { To what extent do you agree that Money } \\
\text { Laundering Act has been able to put } \\
\text { employees of financial institutions on their } \\
\text { right toes against any Money Laundering } \\
\text { related issues? }\end{array}$ & 24.51 & 12.87 & 18.99 & 10.53 & 24.76 & 22.45 \\
\hline
\end{tabular}

